\title{
Tidal Current Pattern in the Surrounding Bintan Island Waters Based on Model Simulation
}

\author{
Ahmad Bayhaqi $i^{1, *}$ Annisa K. Fajari ${ }^{2}$ Dewi Surinati ${ }^{1}$ Nurin Hidayati $^{2}$ \\ ${ }^{1}$ Research Center for Oceanography, Indonesian Institute of Sciences (LIPI), Jakarta, Indonesia \\ ${ }^{2}$ Faculty of Fisheries and Marine Science, Brawijaya University, Malang, Indonesia \\ *Corresponding author. Email: ahmad.bayhaqi@lipi.go.id
}

\begin{abstract}
Observation was conducted in the surrounding Bintan Island Waters to collect the ocean surface current data including moored and stationary recording during first transitional monsoon (March-April). Tidal current pattern in all regions of Bintan Island (north, east and southwest) is simulated using 2D hydrodynamic flow model fm with the flexible mesh and validated by moored observational current resulting a good accuracy rate (more than $80 \%$ ). During flood tide phase, a dominant eastward current occurs in the northern part with the magnitude range $0.36-0.55 \mathrm{~m} / \mathrm{s}$ while northward current happens in the eastern part with the range $0.16-0.22 \mathrm{~m} / \mathrm{s}$. When the ebb tide phase, the reversal current directions from flood tide condition are observed with the magnitude $0.78-1.12 \mathrm{~m} / \mathrm{s}$ and $>0.165 \mathrm{~m} / \mathrm{s}$ for northern and eastern part respectively. On the other hand, the dominant southeastward current continuously occurs in the southwestern part of the island both in flood and ebb tide phase.
\end{abstract}

Keywords: Model simulation, hydrodynamic flow model, tidal current, flood, ebb tide phase, good accuracy rate

\section{INTRODUCTION}

The Indonesian archipelago within the Republic of Indonesia consists of around 17.500 islands [1], where the ocean flows are intercepted creating a complexity in the hydro- oceanographic condition including ocean current pattern. Bintan Island is directly bordered with the Natuna Sea, Karimata Strait and Malacca Strait. Based on the geographical location, which is passed by the Indonesian Throughflow (ITF) pathways, the hydro-oceanographic characteristics in the surrounding waters of Bintan Island is influenced by Natuna Sea as well as monsoonal cycle [2]. In addition, acting as a meeting point of a tidal condition from Malacca Strait and Natuna Sea, the ocean current pattern in Riau archipelago including Bintan Island has a dominant revering tidal current [3].

Many aspects of physical properties such as tidal characteristic and hydro-oceanographic have been investigated in the previous studies using different ways such as direct in situ [2] and global prediction [4]. However, these studies are focused on the smallscale region only, there is a limited information of tidal current in all regions of Banten

Island (north, east and southwest). Furthermore, in order to provide a comprehensive information about ocean current related to all tidal conditions, a numerical approach using model simulation [5] is believed as the most efficient way.

This study attempts to bridge a research gap from previous studies and aims to provide tidal current pattern in all regions of Bintan Island using numerical approach. The results may be a useful information for any coastal developments.

\section{MATH AND METHOD}

In situ measurement was conducted in Bintan Island, Riau archipelago on first transitional monsoon (April) 2019 to collect the ocean surface current data both moored and stationary recording using Recording Current Meter (RCM) Aanderaa. The instrument was deployed for 24 hours, distributed in three regions of the Island; Pengudang (north), Teluk Bakau (east) and Madong (southwest). On the other hand, the stationary recording is located on 38 stations at the surface layer ( 2 meter) with the 1 minute interval recording. All measurement stations can be seen in Figure 1.

Beside the observational data, this study uses the secondary as the input for model simulation such as tide, bathymetry and coastline. The tidal data is retrieved from Indonesian Agency for Geospatial Information (BIG) and NaoTide program. Bathymetry data are based on the Hydrography and Oceanography Center, Indonesian Navy (PUSHIDROSAL), while the coastline of Bintan Island are extracted from NOAA coastline data using A Global Self-Continent, Hierarchical, High- Resolution, Geography (GSHHG) database [6].

The simulation is developed using two equations; continuity and momentum in the $\mathrm{x}-\mathrm{y}$, where: $\mathrm{n}=$ the total of data; $y=$ model value; $y i=$ observation value. 


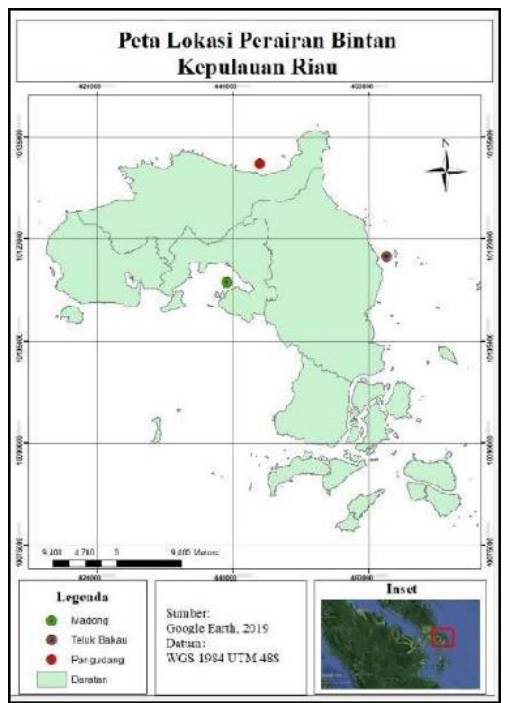

Figure 1 Map of research location including mooring station

\section{RESULTS AND DISCUSSION}

\subsection{Model Validation}

The results of model consist of sea level and current magnitude as well as its direction. Then, model is validated by tidal and current coordinate. The equation involves velocity component (meridional and zonal), sea surface elevation, Coriolis, depth, coefficient eddy viscosity and gravitational force [7]. The model results are validated by moored current from observation and tidal data (BIG and NaoTide). Using the hourly timestep, the results are displayed for the tidal condition; flood and ebb tide in the three regions of island. To figure out the accuracy rate for model result, the calculation of Root Mean Squared Error (RMSE) (Spaulding and Mendelsohn) is conducted using the equation below:

$$
R M S E=\sqrt{\frac{1}{n} \sum_{i=1}^{n}(y-y i)^{2}}
$$

Generally, the model observation data validation. signify a good Root Mean Square (RMSE) value, indicating the accuracy of result (8) for both tidal and current. The RMSE values for tidal data between model result, NaoTIDE and BIG are presented in Table 1.

Table 1. The RMSE value for Tidal Validation in East, Southwest and North part of Bintan Island

\begin{tabular}{lccc}
\hline \multicolumn{1}{c}{ RMSE Value (\%) } & East & Southwest & North \\
\hline Model v NaoTIDE & 15 & 22 & 16 \\
\hline Model v BIG & 19 & 18 & 42 \\
\hline
\end{tabular}

Overall, the RMS value indicates a good percentage with the accuracy above $70 \%$ for all regions in north, east and northwestern. However, the highest RMSE occurs in the northern region with the $46 \%$ between model result and BIG. The further explanation is provided in the next section. In addition, the scatter plot of seal level value in Figure 2 represents that model result is in good agreement. The higher (lower) coefficient of determination $r$ defines the closer (further) model result to the NaoTIDE and BIG.

Generally, there is a high value of $r$ for all regions. However, the same condition with the RMSE, the $r$ value in the northern region has the lowest rate.

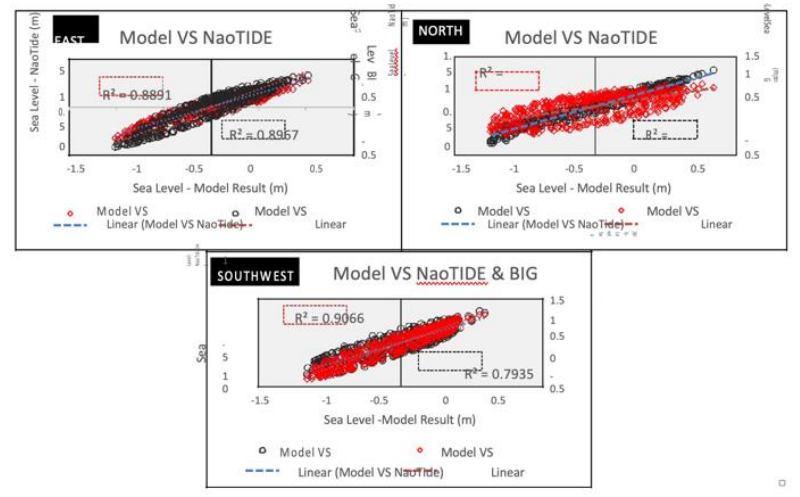

Figure 2 Scatter Plot of Sea Level Value of Model Result, NaoTIDE and BIG

Velocity component from the models are also validated with the mooring observation. Overall, the RMSE value for current component indicates the good rate with above $80 \%$. The value RMS for U component the North, East and Southwest sides are $15.77 \%, 11.77 \%$ and $10 \%$ respectively, while for the $\mathrm{V}$ component in the north are $1.74 \%$, east $11 \%$, and south $15 \%$. The RMSE value for velocity component validation can be seen in the Table 2 .

Table 2. RMSE Value for Velocity component Validation between model and mooring observation

\begin{tabular}{lrrr}
\hline & North & \multicolumn{1}{c}{ East } & Southwest \\
\hline RMSE U & $15.77 \%$ & $11.77 \%$ & $10 \%$ \\
\hline RMSE V & $1.74 \%$ & $11 \%$ & $15 \%$ \\
\hline
\end{tabular}

\subsection{Model Simulation}

In the northern part, the simulation result (Figure 3) showed the dominant eastward current during the flood phase with the magnitude in the range of $0.36-$ $0.4 \mathrm{~m} / \mathrm{s}$. On the other hand, the reversal direction of current is observed during the ebb tide. The dominant westward current with the magnitude of $0.78 \mathrm{~m} / \mathrm{s}$. 

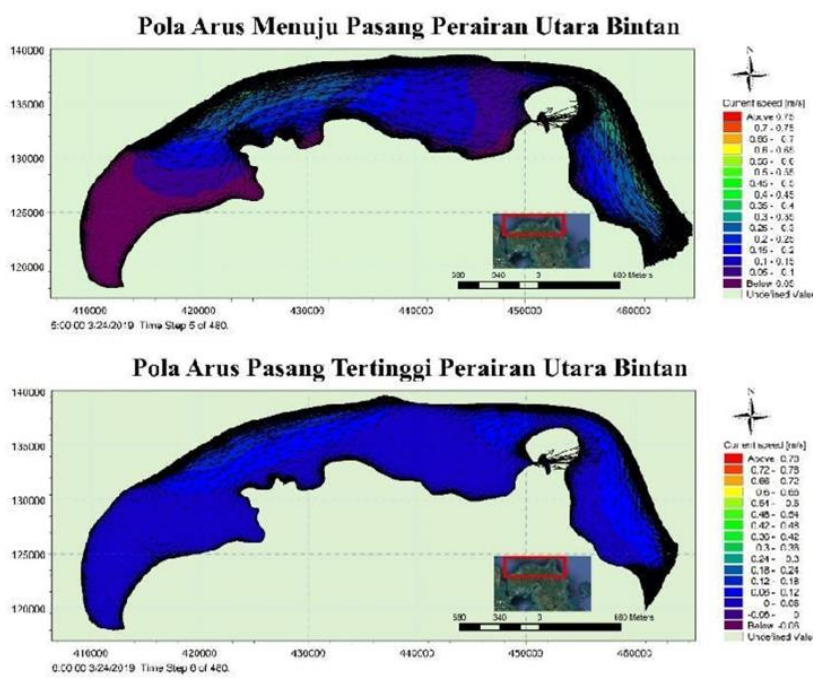

Figure 3 Tidal current pattern in the Northern part. Flood tide phase (above); Ebb tide phase (below)

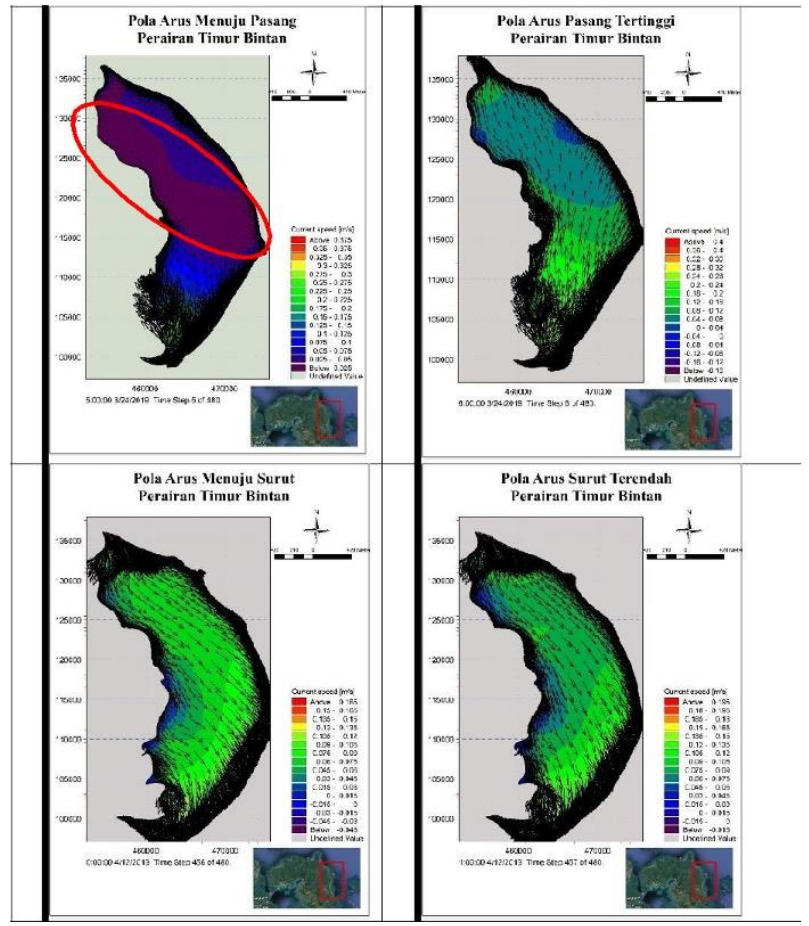

Figure 4 Tidal current pattern in the Eastern part. Flood tide phase (a); Ebb tide phase (d)

The direction of the current heading towards the tide (Figure 4a) in the Eastern waters of Bintan comes from the South (Natuna Sea) heading North along the waters of Bintan Island. The maximum current speed when the state towards the tide reaches $0.2-0.225 \mathrm{~m} / \mathrm{s}$. The current strength weakens again when it reaches the tidal state (Figure $4 \mathrm{~b}$ ) with the current direction from the south with a strong current of $0.16-0.2 \mathrm{~m} / \mathrm{s}$. The direction of the current heading towards the tide that comes from the south meets between the waters of
Bintan and Mapur Island and is split into the mainland of Bintan Island and Mapur Island.

The direction of the current when it is receding until the tide reverses direction with the direction of the current when heading for the tide. Current at low tide (Figure 4c) originates from the north- northwest direction towards the south with a maximum speed > $0.165 \mathrm{~m} / \mathrm{s}$. The dominant current strength is weaker along the eastern waters of Bintan and gets stronger as it approaches the southern side of Bintan Island. The lowest tidal current strength (Figure 4d) reaches > $0.195 \mathrm{~m} / \mathrm{s}$.

Based on Figure 5, the direction of the current going to the tide (Figure 5a) from the north-northwest direction (Singapore Strait) to the southeast. Some of the inflow goes to Bintan Bay. The maximum current speed when the state towards the tide reaches more than 1.5 m.s-1 occurs between the waters of Ujan Island and Bintan Island (the red circle line on the map to the tide). The current stren current direction vector at low tide (Figure $5 \mathrm{c}$ ) originates from the northeast direction (from Bintan Bay) most of it exits towards the south and with a maximum speed reaching 1.04 m.s-1.

The current strength is weaker at low tide (Figure 5d) with a maximum speed reaching more than $0.96 \mathrm{~m} . \mathrm{s}-1$ with the direction of the dominant current going south and part of the current heading north turning towards south. From going down to low tide shows that the current speed is high enough to go low tide and low speed and changes direction at low tide [9]. weakens when it reaches the tide (Figure 5b) with the dominant current direction from the north with a maximum speed reaching $0.65 \mathrm{~m} / \mathrm{s}$ between the waters of Bintan Island and Ujan Island, strengthening of currents occurs between the waters of Ujan Island and Bintan Island [10]. When the current enters the narrowest part of the strait the current will strengthen. This is caused by variations in sea level that causes the slope or slope at sea level (11).

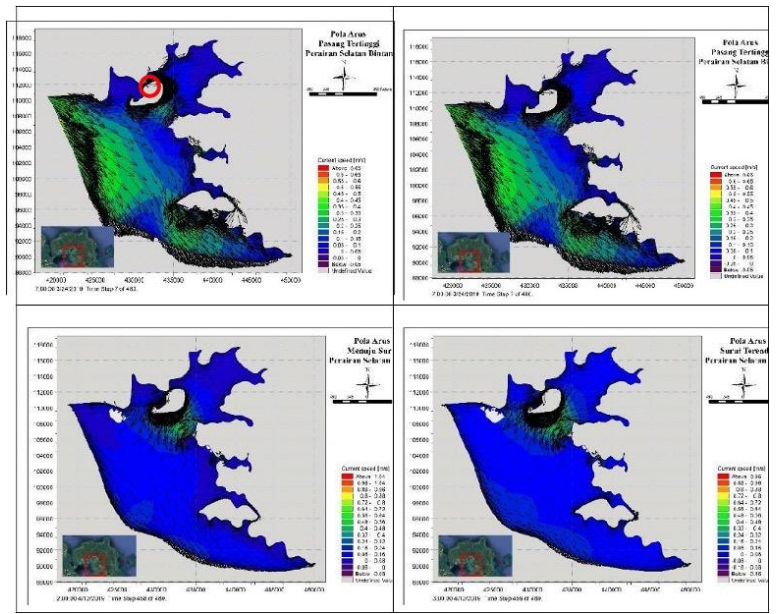

Figure 5 Tidal current pattern in the Southwestern part. Flood tide phase (a); Ebb tide phase (d). 
If the sea surface has a slope, then there will be a horizontal pressure gradient and the mass of water tends to flow from high pressure to low pressure and is balanced by the Coriolis force [12]. The existence of Coriolis force, the water period will be deflected left for water in BBS (Southern Hemisphere) and right for waters in BBU (Northern Hemisphere) [13].

\section{CONCLUSION}

During flood tide phase, a dominant eastward current occurs in the northern part with the magnitude range $0.36-0.55 \mathrm{~m} / \mathrm{s}$ while northward current happens in the eastern part with the range $0.16-0.22 \mathrm{~m} / \mathrm{s}$. When the ebb tide phase, the reversal current directions from flood tide condition are observed with the magnitude $0.78-$ $1.12 \mathrm{~m} / \mathrm{s}$ and $>0.165 \mathrm{~m} / \mathrm{s}$ for northern and eastern part respectively. On the other hand, the dominant southeastward current continuously occurs in the southwestern part of the island both in flood and ebb tide phase.

\section{REFERENCES}

[1] Carpenter, Kent E dan Springer, Victor G. The Center of The Center Marine Shore Fish Biodiversity: The Philipine Island, Environmental Biology of Fisheries 72: 2005, pp. 467-480.

[2] Irawan, Sudra. Kondisi Hidro-Oseanografi Perairan Pulau Bintan (Studi Kasus Perairan Teluk Sasah). Jurnal Kelautan Volume 10, No. 1 ISSN: 1907-9931, 2017, pp. 24769991.

[3] Profil DKP Bintan. .Profil Kelautan dan Perikanan Kabupaten Bintan. 2011.

[4] Sarmada, Iqbal Faiz., Jaya, Yales Veva., dan Putra, Risandi Dwirama. Pemodelan Pola Arus di Kawasan Pesisir Pantai Kawal Kabupaten Bintan. Dinamika Maritim 7(1).2018,pp
[5] Surbaktia, Heron., Purba, Mulia., dan Nurjaya, I Wayan. Pemodelan Pola Arus di Perairan Pesisir Banyuasin, Sumatera Selatan. Maspari Journal 03:2011, pp. 09-14.

[6] Bayhaqi, Ahmad., Wisha, Ulung J., dan Surinati, Dewi. Modeling Tidal Current of Banten Bay During Transitional Monsoons. Jurnal Segara Vol 14 No 2: 2018,pp. 95-105.

[7] Rahmawitri, Herwi., Atmadipoera, Agus Saleh., dan Sukoraharjo, Sri Suryo. Pola Sirkulasi dan Variabilitas Arus di Perairan Selat Sunda. Jurnal Kelautan Nasional Vol. 11, No. 3, 2017,pp. . 141- 157

[8] Budiyanto, Fitri., Arbi, Ucu Yanu., dan Suratno. Risk Assessment on Mercury Cocentration in Six Edible Mollusks from Bintan Island, Indonesia.International Conference on Biology and Applied Science (ICOBAS). 2019.

[9] Magori, Charles. Western Indian Ocean Marine Science Association (WIOMASA) Intergovernmental Oceanographic Commission (of Unesco): Tidal Analysis and Prediction in The Western Indian Ocean. 2008. Kenya Marine and Fisheries Research Institute.

[10] Hernawan, Undang., Geurhaneu, Nineu Yayu., dan Latuputty, Godwin. Karakteristik Pantai dan Bahaya Abrasi di Pulau Putri, Nongsa, Batam. Oseanologi dan Limnologi di Indonesia 3(2): 2018, pp. 137-153.

[11] Tomzack, M dan Godfey, J.S. Regional Oceanography: An Introduction. Australia: Pergamon Press.1994.

[12] Stewart R.H. Introduction to Physical Oceanography. Texas and M University Department of Oceanography.2003.

[13] Danish Hydraulic Institute (DHI). Hydrodynamic Module, Scientific Documentation. Mike 21 Coastal Hydraulics and Oceanography. DHI Software. 2007. 